\title{
Antioxidant Properties and In-Vitro Radical Scavenging Activities of Tannin-Rich and Flavonoid-Rich Fraction of Annona senegelensis and Vernonia amygdalina leaves
}

\author{
*11AJAH, O; ${ }^{2} \mathrm{UNEGBU}, \mathrm{CC} ;{ }^{1} \mathrm{ALAEBO}, \mathrm{PO} ;{ }^{1} \mathrm{ODO}, \mathrm{CE}$
}

\author{
${ }^{*}$ Department of Biochemistry, Michael Okpara University of Agriculture, Umudike, Umuahia Nigeria. \\ ${ }^{2}$ Department of Chemistry /Biochemistry, Federal Polytechnic Nekede Owerri, Nigeria. \\ *Corresponding Author Email: ajah.obinna@mouau.edu.ng
}

\begin{abstract}
Medicinal Plants have demonstrated history of managing some ailments caused by free radicals as a result of some chemical constituents they possess. This study was aimed at assessing antioxidant and free radical scavenging properties of Tannin-rich and Flavoniod-rich fraction of Annona senegelensis and Vernonia amygdalina leaves via in vitro assays such as; reducing power, nitric oxide scavenging activity, Hydrogen peroxide scavenging activity and Lipid peroxidation scavenging activity. The results obtained indicated that both medicinal plants are antioxidant reservoir. The values for Tannin rich fraction of Annona senegelensis (TRFAS) and Tannin rich fraction of Vernonia amygdalina (TRFVA) are Reducing power absorbance TRFAS (0.077-0.187), TRFVA (0.168-0239). \% Nitric oxide scavenging: TRFAS (4.46-30.40), TRFVA (5.23-42.24). $\% \mathrm{H}_{2} \mathrm{O}_{2}$ scavenging: TRFAS (7.30-20.35), TRFVA (8.12-22.32). \% Lipid Perioxidation: TRFAS (6.81-32.76), TRFVA (5.16-26.16). Also the values for Flavonoid rich fraction of Annona senegelensis (FRFAS) and Flavonoid rich fraction of Vernonia amygdalina (FRFVA) are reducing power absorbance: FRFAS (0.109-0.342), FRFVA (0.124-0.388). \% Nitric oxide scavenging: FRFAS (33.55-43.57), FRFVA (21.10-47.46). \% $\mathrm{H}_{2} \mathrm{O}_{2}$ scavenging: FRFAS (39.01-74.96), FRFVA (45.80-75.20). \% Lipid Perioxidation: FRFAS (24.81-59.69), FRFVA (41.43-59.98). The Tannin-rich and Flavonoid-rich fraction of both plants exhibited good antioxidant activity on all models employed at increasing concentrations but Flavoniod-rich fraction of Vernonia amygdalina had the highest inhibitory effect than the Tannin fraction. The findings from this study validated the pharmacological potency of the two plants and their potential use in combating free radical-related diseases, which are often triggered by oxidative stress.
\end{abstract}

\section{DOI:https://dx.doi.org/10.4314/jasem.v25i10.5}

Copyright: Copyright $($ C 2021 Ajah et al. This is an open access article distributed under the Creative Commons Attribution License (CCL), which permits unrestricted use, distribution, and reproduction in any medium, provided the original work is properly cited.

Dates: Received: 22 August 2021; Revised: 17 September 2021; Accepted: 06 October 2021

Keywords: Flavonoid fraction, Tannin fraction, free radical scavenging, Antioxidant, Annona senegelensis,

Free radicals are reactive oxygen species produced by the body during normal metabolism and during the immune response to pathological cell metabolism. They can also be triggered by exogenous chemicals and a variety of environmental factors such as smoke and dust. Free radicals can oxidize biomolecules including RNA, DNA, proteins, and lipids, causing cell membrane lysis, cell death, and tissue damage (Idris et al., 2020). However, Medicinal Plants have shown some demonstrated history of managing some ailments caused by free radicals as a result of some chemical constituents they possess. The identification of medicinal plants with antioxidant potential has become a realistic and powerful tool in ethnomedicine for reducing the complication associated with environmental pollution in humans. Plants contain chemical substances/compounds that allow them to fulfill their responsibilities of preserving human health and curing disease, and phytochemicals are the names given to these compounds (Altemimi et al., 2017). Malaria, cancer, dysentery, filariasis, convulsions, diarrhea, impotency, inflammations, pains, snake bites, and sexually transmitted diseases are among the diseases and symptoms for which A. senegalensis is used in ethnomedicine by various peoples of tropical Africa (Udodeme et al., 2019). According to Udodeme et al (2019), the plant's (A. senegalensis) decoction is used in folkloric medicine to treat kwashiorkor, marasmus, eyelid swelling, and body ache, while the stem bark is used to treat hepatitis, gastroenteritis, guinea worms, toothache, pneumonia, and respiratory infections in Northern Nigeria. Vernonia amygdalina (Astereacea) is a tropical African shrub or small tree that grows to a height of 1 to 5 meters. Bitter leaf is, as its name implies, bitter in taste but shockingly tasty in meals. In Nigeria, bitter leaf is known as, Onugbo in Igbo-Eastern Nigeria, Ewuro (Yoruba), and Shuwaka in Hausa (Bashir et al., 2020). Bitter leaf is a wellcultivated plant with common market merchandise in some African countries such as Nigeria, Cameroon, Ethiopia, and Zimbabwe due to the bitterness of its leaves (Adesonoye and Farombi, 2014). The leaves are 
eaten as an appetizer, and the leaves' extract is used to facilitate digestion in Nigeria. Hausa women in Northern Nigeria eat it with the belief that it improves sexual attractiveness (Oyeyemi et al., 2018). Leaf extracts of $V$. amygdalina in Nigeria are used in ethnomedicines for treatment of diabetes (Akwasi, 2018). Therefore, it is clear that these plants contains chemical constituents responsible for its pharmacological actions. This study was designed to evaluate the antioxidant and radical scavenging activities of Tannin and Flavoniod-rich fraction of Annona sengalensis and Vernonia amygdalina leaves in vitro.

\section{MATERIALS AND METHODS}

Plant Collection: Fresh leaves of Annona senegalensis and Vernonia amygdalina were collected from Nekede Owerri, Imo State Nigeria. The plants were identified and authenticated by a Plant Taxonomist at Michael Okpara University of Agriculture Umudike.

Preparation of Plant Sample: The fresh leaves of Annona senegalensis and Vernonia amygdalina were washed and allowed to dry to a constant weight and pulverized into powder using Pulverizer (5126 TP).

Extraction of tannin rich fraction: The powdered sample of Annona sengalensis and Vernonia amygdalina leaves $(100 \mathrm{~g})$ were weighed and each of the sample was defatted with petroleum ether in a mechanical shaker for $48 \mathrm{hrs}$ at room temperature. Then it was extracted with aqueous acetone and water at $420 \mathrm{ml}$ and $180 \mathrm{ml}$ respectively for $60 \mathrm{~min}$ at $60^{\circ} \mathrm{c}$ in water bath with constant stirring. The mixture was then filtered and centrifuged at 300rpm for 10mins. The filtrate was allowed to evaporate at room temperature. The acetone free extract was lyophilized and the powdered sample was collected, weighed and stored in sterile bottle at $4^{\circ} \mathrm{c}$ in a refrigerator for further study.

Flavonoid Extraction: Five hundred gram (500g) of powdered leaves was macerated in $80 \%$ methanol at room temperature for $72 \mathrm{~h}$. It was continuously mixed and then filtered using a filter paper (Whatman size No.1). The filtrate was dried in a water bath at $45^{\circ} \mathrm{C}$ and concentrate was kept in air tight bottle at $4^{\circ} \mathrm{C}$ until used. The concentrate obtained from each sample was subsequently extracted in petroleum ether, diethyl ether and ethyl acetate following the method of Subramanian and Nagarajan (1969). Petroleum ether fraction was discarded due to its being rich in fatty substances. Ether fraction was used for free flavonoids whereas ethyl acetate fraction for bound flavonoids. Ethyl acetate fraction of each sample was hydrolysed further with $7 \%$ Sulphuric acid for 24 hours and was then re-extracted with ethyl acetate. The fraction obtained was repeatedly washed with distilled water to neutrality, dried and weighed.

\section{In-vitro antioxidant Analysis}

Determination of total phenol content: Total phenolic content was determined by Folin Ciocalteu's method as described by Bhalodia et al. (2011) and Patel et al. (2010) with slight modification.

Determination of total flavonoid content: Total flavonoid content was determined using aluminium chloride colorimetric assay as used by Patel et al. (2010); Pallab et al. (2013) and Satish et al. (2008).

Reducing power Assay: Following the report of Kowsalya and Namasivayam (2014), the $\mathrm{Fe}^{3+}$ reducing power of the plants was determined by the method of (Oyaizu, 1986) with a slight modification. Different concentrations (200-800 $\mu \mathrm{g} \mathrm{mL}-1)$ of the extracts were mixed with $2.5 \mathrm{~mL}$ phosphate buffer $(0.2$ $\mathrm{M}, \mathrm{pH}$ 6.6) and $2.5 \mathrm{~mL}$ potassium hexa cyanoferrate ( $1 \%)$, followed by incubation at $50^{\circ} \mathrm{C}$ in a water bath for $20 \mathrm{~min}$. After incubation, $2.5 \mathrm{~mL}$ of TCA (10\%) was added to terminate the reaction. The upper portion of the solution $(2.5 \mathrm{~mL})$ was mixed with $2.5 \mathrm{~mL}$ distilled water and $0.5 \mathrm{~mL} \mathrm{FeCl}_{3}$ solution $(0.1 \%)$ was added. The reaction mixture was left for $10 \mathrm{~min}$ at room temperature and the absorbance was measured at $700 \mathrm{~nm}$ against an appropriate blank solution. A higher absorbance of the reaction mixture indicated greater reducing power. Ascorbic acid was used as a reference standard.

Nitric oxide radical scavenging activity: Nitric oxide radical scavenging activity was assayed according to the method reported by Kowsalya and Namasivayam (2014). Nitric oxide was generated from sodium nitro prusside in aqueous solution at physiological $\mathrm{pH}$, which interacts with oxygen to produce nitric ions, which may be determined by the Griess Illosvoy reaction. The $2.0 \mathrm{~mL}$ of $10 \mathrm{mM}$ sodium nitro prusside, $0.5 \mathrm{~mL}$ phosphate buffer saline $(\mathrm{pH} 7.4)$ was mixed with $0.5 \mathrm{~mL}$ of sample at different concentrations and the mixture was incubated at $25^{\circ} \mathrm{C}$ for $150 \mathrm{~min}$. From the incubated mixture $1.5 \mathrm{~mL}$ was taken out and added into $1.0 \mathrm{~mL}$ of griess reagent (1\% sulphanilamide, $2 \%$ O-phosphoric acid, $1 \%$ napthyl ethylene diamine di $\mathrm{HCl}$ ) and incubated at room temperature for $5 \mathrm{~min}$. The absorbance of the mixture was measured at $546 \mathrm{~nm}$.

Hydrogen peroxide scavenging assay: This activity was determined according to a previously described method by Floriano-Sanchez et al. (2006) with minor changes in the report of Kowsalya and Namasivayam 
(2014). An aliquot of $50 \mathrm{mM} \mathrm{H}_{2} \mathrm{O}_{2}$ and various concentrations $(200-800 \mu \mathrm{g} \mathrm{mL}-1)$ of samples were mixed $(1: 1 \mathrm{v} / \mathrm{v})$ and incubated for $30 \mathrm{~min}$ at room temperature. After incubation, $90 \mu \mathrm{L}$ of the $\mathrm{H}_{2} \mathrm{O}_{2}$ sample solution was mixed with $10 \mu \mathrm{L}$ HPLC-grade methanol and $0.9 \mathrm{~mL}$ FOX reagent was added (4.4 $\mathrm{mM}$ BHT added in 9 volumes of Methanol and 1 volume of $1 \mathrm{mM}$ xylenol Orange, $2.56 \mathrm{mM}$ Ammonium ferrous sulphate in $0.25 \mathrm{M} \mathrm{H} 2 \mathrm{SO} 4)$. The reaction mixture was then vortexed and incubated at $37^{\circ} \mathrm{C}$ for $30 \mathrm{~min}$. The absorbance of the ferric-xylenol orange complex was measured at $560 \mathrm{~nm}$.

Lipid Peroxidation Assay: Lipid peroxidation assay was carried out by measuring lipid peroxide content and the conjugated diene formation and the method of Salawu et al. (2006) was employed.

Lipid Peroxide Formation: A modified thiobarbituric acid reactive species (TBARS) assay was used to measure the lipid peroxide formed using egg yolk homogenates as lipid rich media. Egg yolk homogenate was prepared according to a standard method. Malondialdehyde (MDA), a secondary end product of the oxidation of polyunsaturated fatty acids, reacts with two molecules of thiobarbituric acid (TBA) yielding a pinkish red chromogen with absorbance maximum at $532 \mathrm{~nm}$. Egg homogenate $(0.5 \mathrm{~mL}$ of $10 \% \mathrm{v} / \mathrm{v}$ ) and $0.1 \mathrm{~mL}$ of each extract were added to a test tube and made up to $1 \mathrm{~mL}$ with distilled water. $0.05 \mathrm{~mL}$ of FeSO4 $(0.07 \mathrm{M})$ was added to induce lipid peroxidation and incubated for $30 \mathrm{~min}$. Then $1.5 \mathrm{~mL}$ of $20 \%$ acetic acid ( $\mathrm{pH}$ adjusted to 3.5 with $\mathrm{NaOH}$ ) and $1.5 \mathrm{~mL}$ of $0.8 \%(\mathrm{w} / \mathrm{v})$ TBA in $1.1 \%$ sodium deodecyl sulphate and 20\% TCA were added and the resulting mixtures were vortexed and then heated at $95^{\circ} \mathrm{C}$ for $60 \mathrm{~min}$. After cooling, $5.0 \mathrm{~m}$ of butan-1-ol was added to each tube and centrifuged at $3000 \mathrm{rpm}$ for $10 \mathrm{~min}$. The absorbance of the organic layer was measured at $532 \mathrm{~nm}$. Inhibition of lipid peroxide formation $(\%)$ by the extract was calculated according to $[(1-\mathrm{E} / \mathrm{C}) \times 100]$ where $\mathrm{C}$ is the absorbance value of the fully oxidized control and $\mathrm{E}$ is (Abs 532+TBAAbs532-TBA).

\section{RESULTS AND DISCUSSION}

The present study indicates the in-vitro antioxidant activity of Isolated Tannins and Flavoniods from Annona senegalensis and Vernonia amygdalina leaves. Phytochemicals studies have confirmed and justified the use of these folkoric herbs. The results (Tables 1 to 10) from the current study clearly justified the use of both medicinal plants in the management various pathologic conditions. It gives protection against various free radicals. There was significant $(\mathrm{p}<0.05)$ increase in a dose dependent manner of the reducing power ability of the two plants with Vernonia amygdalina having more potency compared to Annona senegalensis. There was significant $(\mathrm{p}<0.05)$ increase in a dose dependent manner of the percentage nitric oxide scavenging ability of the two plants with Vernonia amygdalina having more potency compared to Annona senegalensis. There was significant $(\mathrm{p}<0.05)$ increase in a dose dependent manner of the percentage Hydrogen peroxide inhibition of the two plants with $400 \mu \mathrm{g} / \mathrm{m}$ and $600 \mu \mathrm{g} / \mathrm{m}$ of Annona senegalensis having more potency compared to $400 \mu \mathrm{g} / \mathrm{m}$ and $600 \mu \mathrm{g} / \mathrm{m}$ of Vernonia amygdalina. Although the ascorbic acid has more percentage Hydrogen peroxide inhibition.

There was significant $(\mathrm{p}<0.05)$ increase in a dose dependent manner of the Lipid Peroxidation scavenging ability of the two plants with $800 \mu \mathrm{g} / \mathrm{m}$ of Annona senegalensis having more potency than Vernonia amygdalina. Although the ascorbic acid has more Lipid Peroxidation scavenging ability. For the tannin fraction of both plants, there was significant $(\mathrm{p}<0.05)$ increase in a dose dependent manner of the reducing power ability of the two plants with Vernonia amygdalina having slightly more potency compared to Annona senegalensis. The flavonoid fraction from both plant have more reducing power than the Tannin fraction.

There was significant $(p<0.05)$ increase in a dose dependent manner of the percentage nitric oxide scavenging ability of the two plants with Vernonia amygdalina having more potency compared to Annona senegalensis. Although the $200 \mu \mathrm{g} / \mathrm{m}$ of Annona senegalensis has higher \% ihnibition of Nitric oxide than the $200 \mu \mathrm{g} / \mathrm{m}$ of Vernonia amygdalina. There was also significant $(\mathrm{p}<0.05)$ increase in a dose dependent manner of the Lipid Peroxidation scavenging ability of the two plants.

Different models used to evaluate the antioxidant activity suggests that the fractions from $V$. amygdalina and $A$. senegalensis showed good source of natural antioxidants. Based on the result of analysis for the Tannin-rich fraction, increasing concentration showed some significant increase in absorbance. $V$. amygdalina tannin-rich fraction exhibited strong reducing power effect at $400 \mu \mathrm{g} / \mathrm{ml}$ but had little reducing power effect as the concentration increased (Table 3). TRFAS and TRFVA exhibited scavenging effect on nitric oxide radical $\left(\mathrm{NO}^{+}\right)$at increasingly high concentration while the Ascorbic acid exhibited the highest effect (Table 4). However, the $\mathrm{H}_{2} \mathrm{O}_{2}$ scavenging activity of Tannin-rich fraction of both plants was relatively low on comparison to Ascorbic acid standard (Table 5). Although TRFAS and TRFVA showed some scavenging ability to donate electrons to $\mathrm{H}_{2} \mathrm{O}_{2}$ and neutralize it to water at 
increasing concentrations. The percentage inhibition of lipid peroxidation by TRFAS and TRFVA were relatively low when compared with Ascorbic acid.
However, TRFVA had more lipid peroxidation activity than TRFAS at concentrations of $400 \mu \mathrm{g} / \mathrm{ml}$ and $600 \mu \mathrm{g} / \mathrm{ml}$ (Table 6).

Table 1: Total Phenolics and Total Flavonoids of Tannin- Rich Fraction of Annona senegalensis (TRFAS) and Vernonia amygdalina (TRFVA) Leave

\begin{tabular}{lll}
\hline Samples & $\begin{array}{l}\text { Total Phenolics } \\
(\mathrm{mgGAE} / \mathrm{g})\end{array}$ & $\begin{array}{l}\text { Total flavonoids } \\
\text { (mgQCE/g) }\end{array}$ \\
\hline Tannin Rich Fraction of Annona senegalensis (TRFAS) & $32.96 \pm 2.80$ & $28.46 \pm 1.16$ \\
Tannin Rich Fraction of Vernonia amygdalina TRFVA & $38.07 \pm 5.94$ & $36.25 \pm 2.56$ \\
Flavonoid Rich Fraction of Annona senegalensis (FRFAS) & $56.15 \pm 4.63$ & $126.04 \pm 7.28$ \\
Flavonoid Rich Fraction of Vernonia amygdalina (FRFVA) & $52.49 \pm 3.67$ & $164.18 \pm 4.32$ \\
\hline
\end{tabular}

The Flavoniods-rich fraction of both plants revealed that they had a good scavenging activity to reduce Fe ${ }^{3+} \rightarrow \mathrm{Fe}^{2+}$ at increasing concentration when compared to the standard (table 7). At Concentration of $200 \mu \mathrm{g} / \mathrm{ml}$, FRFAS had high Nitric oxide scavenging activity than FRFVA while at $600 \mu \mathrm{g} / \mathrm{ml}$, the both fractions had the same activity. FRFVA showed more activity at $400 \mu \mathrm{g} / \mathrm{m}$ and $800 \mu \mathrm{g} / \mathrm{ml}$ respectively than FRFAS (Table 8). However, ascorbic acid exhibited the greatest effect. FRFVA showed high $\mathrm{H}_{2} \mathrm{O}_{2}$ scavenging activity at $200 \mu \mathrm{g} / \mathrm{ml}$ than FRFAS. At $400 \mu \mathrm{g} / \mathrm{ml}$ FRFAS demonstrated a higher scavenging activity than FRFVA. But at $600 \mu \mathrm{g} / \mathrm{ml}$ and $800 \mu \mathrm{g} / \mathrm{ml}$ FRFVA exhibited greater activity over FRFAS. Nevertheless, both fractions exhibited increasing antioxidant activity on comparison to standard (Table 9). However, at increasing concentrations, both FRFAS and FRFVA had higher lipid peroxidation activity but had almost same activity at concentration of $800 \mu \mathrm{g} / \mathrm{ml}$ (Table 8). At $200 \mu \mathrm{g} / \mathrm{ml}$ and $400 \mu \mathrm{g} / \mathrm{ml}$ concentrations, the activity of the FRFAS and FRFVA was relatively same as the standard Ascorbic acid (Table 8).

Table 2: IC50 of the various Scavenging activities of Tannin- Rich Fraction of Annona senegalensis (TRFAS) and Vernonia amygdalina

\begin{tabular}{lllll}
\multicolumn{3}{c}{ (TRFVA) Leave } & & \\
\hline Samples & $\begin{array}{l}\text { Reducing } \\
(\mu \mathrm{g} / \mathrm{m})\end{array}$ & $\begin{array}{l}\text { Power } \\
\text { Nitric Oxide } \\
\text { Scavenging } \\
(\mu \mathrm{g} / \mathrm{m})\end{array}$ & $\begin{array}{l}\mathrm{H}_{2} \mathrm{O}_{2} \\
\text { Scavenging } \\
(\mu \mathrm{g} / \mathrm{m})\end{array}$ & $\begin{array}{l}\text { Lipid } \\
\text { Peroxidation } \\
(\mu \mathrm{g} / \mathrm{m})\end{array}$ \\
\hline Tannin Rich Fraction of Annona senegalensis (TRFAS) & $1399.59 \pm 95.54$ & $6.11 \pm 1.06$ & $10.65 \pm 2.18$ & $5.19 \pm 1.03$ \\
Tannin Rich Fraction of Vernonia amygdalina TRFVA & $2920.61 \pm 125.18$ & $4.23 \pm 0.85$ & $10.28 \pm 1.63$ & $6.89 \pm 1.64$ \\
Flavonoid Rich Fraction of Annona senegalensis (FRFAS) & $647 . .53 \pm 62.74$ & $5.75 \pm 1.65$ & $1.45 \pm 0.08$ & $2.86 \pm 0.25$ \\
Flavonoid Rich Fraction of Vernonia amygdalina (FRFVA) & $540.48 \pm 34.98$ & $3.94 \pm 0.72$ & $1.54 \pm 0.82$ & $2.39 \pm 0.61$ \\
Ascorbic acid & $249.73 \pm 35.85$ & $2.18 \pm 0.54$ & $0.24 \pm 0.04$ & $1.59 \pm 0.34$ \\
\hline
\end{tabular}

The results are mean $\pm S D$. The lower the IC50 the higher the antioxidant activity.

Table 3: Reducing power ability of Tannin- Rich Fraction of Annona senegalensis (TRFAS) and Vernonia amygdalina (TRFVA) Leave

\begin{tabular}{llll}
\hline Concentration $(\mu \mathrm{g} / \mathrm{m})$ & Absorbance of TRFAS & Absorbance of TRFVA & Absorbance of Standard Ascorbic Acid \\
\hline 200 & $0.077 \pm 0.01$ & $0.168 \pm 0.03$ & $0.976 \pm 0.06$ \\
400 & $0.102 \pm 0.03$ & $0.602 \pm 0.05$ & $1.193 \pm 0.05$ \\
600 & $0.129 \pm 0.01$ & $0.219 \pm 0.02$ & $1.325 \pm 0.11$ \\
800 & $0.187 \pm 0.04$ & $0.239 \pm 0.01$ & $1.589 \pm 0.08$ \\
\hline \multicolumn{2}{r}{ The results are mean $\pm S D$ of triplicate determination. }
\end{tabular}

Table 4: Percentage Nitric oxide Scavenging of Tannin- Rich Fraction of Annona senegalensis (TRFAS) and Vernonia amygdalina (TRFVA) Leave

\begin{tabular}{llll}
\hline Concentration $(\mu \mathrm{g} / \mathrm{m})$ & $\%$ inhibition of TRFAS & $\%$ inhibition of TRFVA & $\%$ inhibition of Standard Ascorbic Acid \\
\hline 200 & $4.46 \pm 0.16$ & $5.23 \pm 0.82$ & $62.20 \pm 3.14$ \\
400 & $22.99 \pm 1.42$ & $31.21 \pm 1.78$ & $71.70 \pm 1.92$ \\
600 & $25.77 \pm 1.08$ & $37.68 \pm 1.24$ & $74.90 \pm 2.86$ \\
800 & $30.40 \pm 2.17$ & $42.24 \pm 5.02$ & $76.30 \pm 4.10$ \\
\hline
\end{tabular}

The results are mean $\pm S D$ of triplicate determination

Medicinal plants are significant source of efficient chemotherapeutics, which are critical for human health maintenance. In terms of mechanism of action, biological properties, and chemical structures, these phyto-compounds are special (Arika et al., 2019). Antioxidants counteract the effects of free radicals by either reacting with, neutralizing, or fighting for substrates with molecular oxygen $\left(\mathrm{O}_{2}\right)$ as their terminal electron acceptor (Arika et al., 2019; Lallianrawna, 2013). Antioxidant compounds and phytochemicals abundant in medicinal plants are thought to be responsible for these plants' therapeutic properties (Ekaluo et al., 2015). 
Table 5: Hydrogen Peroxide Scavenging of Tannin- Rich Fraction of Annona senegalensis (TRFAS) and Vernonia amygdalina (TRFVA)

\begin{tabular}{llll}
\hline Concentration $(\mu \mathrm{g} / \mathrm{m})$ & \% inhibition of TRFAS & \% inhibition of TRFVA & \%inhibition of Standard Ascorbic Acid \\
\hline 200 & $7.30 \pm 1.05$ & $8.12 \pm 0.74$ & $57.50 \pm 4.12$ \\
400 & $13.88 \pm 1.42$ & $11.48 \pm 1.34$ & $73.40 \pm 1.54$ \\
600 & $17.84 \pm 2.04$ & $14.85 \pm 2.05$ & $86.65 \pm 3.02$ \\
800 & $20.35 \pm 0.98$ & $22.32 \pm 1.18$ & $94.42 \pm 5.46$ \\
\hline
\end{tabular}

The results are mean $\pm \mathrm{SD}$ of triplicate determination.

Table 6: Lipid Peroxidation scavenging of Tannin-Rich Fraction of Annona senegalensis (TRFAS) and Vernonia amygdalina (TRFVA)

\begin{tabular}{llll}
\hline Concentration $(\mu \mathrm{g} / \mathrm{m})$ & \% inhibition of TRFAS & \% inhibition of TRFVA & \% inhibition of Standard Ascorbic Acid \\
\hline 200 & $6.81 \pm 0.58$ & $5.16 \pm 0.82$ & $41.84 \pm 2.16$ \\
400 & $8.66 \pm 0.72$ & $18.32 \pm 1.65$ & $51.63 \pm 1.34$ \\
600 & $16.99 \pm 1.03$ & $26.08 \pm 3.14$ & $78.60 \pm 6.83$ \\
800 & $32.76 \pm 1.68$ & $26.16 \pm 1.26$ & $91.15 \pm 5.17$ \\
\hline
\end{tabular}

The results are mean \pm SD of triplicate determination.

Table 7: Reducing power ability of Flavonoid- Rich Fraction of Annona senegalensis (FRFAS) and Vernonia amygdalina (FRFVA) Leave

\begin{tabular}{llll}
\hline Concentration $(\mu \mathrm{g} / \mathrm{m})$ & $\begin{array}{l}\text { Absorbance of } \\
\text { flavonoid- } \\
\text { Rich Fraction }\end{array}$ & $\begin{array}{l}\text { Absorbance of } \\
\text { flavonoid- rich } \\
\text { Fraction }\end{array}$ & $\begin{array}{l}\text { Absorbance of } \\
\text { Standard } \\
\text { Ascorbic Acid }\end{array}$ \\
\hline 200 & $0.109 \pm 0.03$ & $0.124 \pm 0.04$ & $0.977 \pm 0.05$ \\
400 & $0.145 \pm 0.01$ & $0.151 \pm 0.02$ & $1.198 \pm 0.12$ \\
600 & $0.218 \pm 0.05$ & $0.284 \pm 0.07$ & $1.324 \pm 0.08$ \\
800 & $0.342 \pm 0.05$ & $0.388 \pm 0.02$ & $1.588 \pm 0.04$ \\
\hline \multicolumn{4}{c}{ The results are mean $\pm S D$ of triplicate determination }
\end{tabular}

Table 8: Percentage Nitric Oxide Scavenging of flavonoid - Rich Fraction of Annona senegalensis (FRFAS) and Vernonia amygdalina

\begin{tabular}{llll}
\multicolumn{4}{c}{ (FRFVA) Leave } \\
\hline $\begin{array}{l}\text { Concentration } \\
(\mu \mathrm{g} / \mathrm{m})\end{array}$ & $\begin{array}{l}\text { \% inhibition } \\
\text { of FRFAS }\end{array}$ & $\begin{array}{l}\text { \% inhibition } \\
\text { of FRFVA }\end{array}$ & $\begin{array}{l}\text { \% inhibition of } \\
\text { Standard } \\
\text { Ascorbic Acid }\end{array}$ \\
\hline 200 & $33.55 \pm 4.13$ & $21.10 \pm 2.64$ & $62.20 \pm 5.18$ \\
400 & $40.19 \pm 2.15$ & $48.43 \pm 1.78$ & $71.70 \pm 5.83$ \\
600 & $41.70 \pm 5.81$ & $41.38 \pm 3.25$ & $74.90 \pm 3.98$ \\
800 & $43.57 \pm 3.92$ & $47.46 \pm 2.84$ & $76.30 \pm 4.73$ \\
\hline
\end{tabular}

Table 9: Hydrogen Peroxide Scavenging of flavonoid - Rich Fraction of Annona senegalensis (FRFAS) and Vernonia amygdalina (FRFVA) Leave

\begin{tabular}{llll}
\hline $\begin{array}{l}\text { Concentration } \\
(\mu \mathrm{g} / \mathrm{m})\end{array}$ & $\begin{array}{l}\% \text { inhibition } \\
\text { of FRFAS }\end{array}$ & $\begin{array}{l}\% \text { inhibition } \\
\text { of FRFVA }\end{array}$ & $\begin{array}{l}\text { \% inhibition of } \\
\text { Standard } \\
\text { Ascorbic Acid }\end{array}$ \\
\hline 200 & $39.01 \pm 2.62$ & $45.80 \pm 4.65$ & $57.50 \pm 2.18$ \\
400 & $65.50 \pm 4.17$ & $51.63 \pm 6.12$ & $73.40 \pm 7,24$ \\
600 & $66.08 \pm 2.41$ & $67.52 \pm 2.43$ & $86.65 \pm 5.31$ \\
800 & $74.96 \pm 3.86$ & $75.20 \pm 1.94$ & $94.42 \pm 4.93$ \\
\hline
\end{tabular}

The results are mean $\pm S D$ of triplicate determination. There was significant $(p<0.05)$ increase in a dose dependent manner of the percentage Hydrogen peroxide inhibition of the two plants. Although the ascorbic acid has more percentage Hydrogen peroxide inhibition.

Table 10: Lipid Peroxidation Scavenging of flavonoid - Rich Fraction of Annona senegalensis (FRFAS) and Vernonia amygdalina

\begin{tabular}{llll}
\multicolumn{5}{c}{$\begin{array}{c}\text { (FRFVA) Leave } \\
(\mu \mathrm{g} / \mathrm{m})\end{array}$} & $\begin{array}{l}\text { \% inhibition } \\
\text { of FRFAS }\end{array}$ & $\begin{array}{l}\% \text { inhibition } \\
\text { of FRFVA }\end{array}$ & $\begin{array}{l}\% \text { inhibition of } \\
\text { Standard } \\
\text { Ascorbic Acid }\end{array}$ \\
\hline 200 & $24.81 \pm 2.74$ & $41.43 \pm 2.17$ & $41.84 \pm 3.16$ \\
400 & $47.71 \pm 4.12$ & $48.22 \pm 3.15$ & $51.63 \pm 4.23$ \\
600 & $51.91 \pm 5.31$ & $52.91 \pm 2.83$ & $78.60 \pm 3.86$ \\
800 & $59.69 \pm 3.62$ & $59.98 \pm 1.95$ & $91.15 \pm 7.13$ \\
\hline \multicolumn{4}{c}{ The results are mean \pm SD of triplicate determination. }
\end{tabular}

Both fractions showed some does-dependent free radicals scavenging activity. Furthermore, Ryszard (2007) in his review highlighted that Tannins are good and a new natural antioxidants but do not function solely as primary antioxidants but also as a secondary antioxidant. The antioxidant properties of plants are related to the extent of Proanthocyanidins content because proanthocyanidins (Condensed Tannins) are oligomeric and polymeric products of flavonoid biosynthetic pathway (Lutigen, 2018), which was 
confirmed in an aforementioned study of Ryszard (2007), and was also confirmed in the study of Lingxi et al. (2020) in which condensed tannin gave a strong antioxidant effect but the combination of hydrolyszable and condensed tannin was more potent. Additionally, most phenolic compounds have been associated with antioxidant properties. The antioxidant activity of $V$. amygdalina due to the flavonoid fraction was in line with the report of Igile et al. (1994). Flavoniods are known for their widespread health benefits in respect to managing oxidative stress due to their hydroxyl group $\left(\mathrm{OH}^{-}\right)$ directly bonded to the benzene ring, thus allowing them to easily donate electrons to electron-deficient radicals (Ekaluo et al., 2015). Going further, A. senegelensis in a previous study conducted by Fahun et al. (2018) demonstrated some antioxidative effect which could be attributed to the presence of Flavoniods. This study justifies the claims for the use of Annona senegelensis and Vernonia amygdalina for treating ailments.

Conclusion: The tannin-rich fraction and flavoniod fraction of Vernonia amygdalina and Annona senegalensis leaves in this study was found to possess potent antioxidants. The different models employed in evaluating the antioxidant activity suggested that both plants are good source of natural antioxidants and hence has lend credence to the use of both plants in the management of oxidative stress associated diseases.

\section{REFERENCES}

Adesanoye, AO; Farombi, EO (2014). In Vitro Antioxidant properties of Methanolic Leaf extract of Vernonia Amygdalina Del. Niger. J. Physiol. Sci. 29:091-101.

Akwasi, B (2018). A Comparative Chemistry of coa Herbal Medicine and herbal extracts of Vernonia amygdalina (bitter leaf) and Persea americana (Avocado). Masters of Medical Science (M.MedSc), College of Health Science University of KwaZulu-Natal (Westville Campus).

Altemimi, A; Lakhssassi, N; Baharlouei, A; Watson, DG; Lightfoot, DA (2017). Phytochemicals: Extraction, isolation, and identification of bioactive compounds from plant extracts. Plants. $6(4): 42$

Arika, W; Kibiti, CM; Njagi, JM; Ngugi, MP (2019). In vitro Antioxidant properties of Dichloromethanolic Leaf Extract of Gnidia glauca (Fresen) as a Promising Antiobesity Drug. J. Evid.-Based Integ. Med. 24: 1-17.
Bashir, RA; Mukhtar, Y; Chimbekujwo, IB; Aisha, DM; Fatima, SU; Salamatu, SU (2020). Phytochemical screening and Fourier Transform Infrared Spectroscopy (FT-IR) Analysis of Vernonia amygdalina Del. (Bitter leaf) Methanol Leaf Extract. FUTY J. Environ. 14(2):35-41.

Bhalodia, N; Nariya, P; Acharya, R; Shukla, V (2011). Evaluation of in vitro antioxidant activity of flowers of Cassia fistula Linn. Int. J. Pharm Tech Res., 3(1): 589-599.

Ekaluo, UB; Ikpeme, EV; Ekerette, EE; Chukwu, CI (2015). In vitro Antioxidant and free Radical Activity of some Nigerian Medicinal Plants: Bitter Leaf (Vernonia amygdalina L.) and Guava (Psidium guajava Del.). Res. J. Med. Plant, 9 (5): 215-226.

Fayun, IL; Buba, CI; Atogwe, J; Okeoma, DC; Okhali, SE (2018). Phytochemical analysis, antioxidant activity and growth inhibitory effects of extracts from Annona senegalensis, Walthleria indica and Anthocleista vogeli. Int. J. Pharmacog. 5(11):692-699.

Floriano-Sanchez, E; Villanueva, C; Medina-Campos, ON; Rocha, D; Sanchez-Gonzalez, DJ; CardenasRodriguez, N; Pedraza-Chaverri, J (2006). Nordihydroguaiaretic acid is a potent in vitro scavenger of peroxynitrite, singlet oxygen, hydroxyl radical, superoxide anion and hypochlorous acid and prevents in vivo ozoneinduced tyrosine nitration in lungs. Free Radical Res 40(5):523-533

Idris, AK; Gayus, AM; Ibrahim, A (2020). Comparative analysis of Antioxidant potential of the fractions of Methanolic Root Bark extract of Annona senegalensis. Int. J. Inno. Sci. Res. Tech. 5(2):689-694.

Igile, GO; Oleszek, W; Jurzysta, M; Burda, S; Fafunso, M; Fassanamade, AA (1994). Flavoniods from Vernonia amygdalina and their antixodant activities. J. Agric. Food Chem. 42: 2445-2448.

Kowsalya, R; Namasivayam, E (2014). In vitro Antioxidant and free radical scavenging activity of Isolongifolene. Asian J. Bio. Sci. 7:1323.

Lingxi, L; Thie, L; Zongmin, W; Weichao, Y; Yan, C (2020). Effect of tanning addition on chromatic characteristics sensory qualities and antioxidant 
activities of red wine. Royal Soc. Chem. 10:71087117.

Lallianrawna, S (2013). Isolation, Purification and Identification of Bio-active components with Potential pesticidal properties from plant extracts and their interaction with transition metal ions (Dissertation). Aizawl, Mizoram, India: Mizoram University.

Lutgen, P (2018). Tannins in Artemisia: the hidden treasure of prophylaxis. Pharm. Pharmacol. Int. J. 6(3):176-181

Oyaizu, M (1986). Studies on products of browning reactions: Antioxidative activities of product of browning reaction prepared from Glucosamine. Japan J. Nutrition, 44:307-315.

Oyeyemi, IT; Akinlabi, AA; Adewumi, A; Aleshinloye, AO; Oyeyemi, OT (2018). Vernonia amygdalina: A folkloric herb with anthelminthic properties. Beni-Suef Uni. J. Basic Appl. Sci. $7: 43-49$.

Pallab, K; Tapan, B; Tapas, P; Ramen, K (2013). Estimation of total flavonoids content (TPC) and antioxidant activities of methanolic whole plant extract of Biophytum sensitivum Linn. J. Drug Del. Therap, 3(4): 33-37.
Patel, A; Patel, A; Patel, A; Patel, NM (2010). Estimation of flavonoid, polyphenolic content and in vitro antioxidant capacity of leaves of Tephrosia purpurea Linn. (Leguminosae). Int. J. Pharm. Sci. Res. 1(1): 66-77.

Ryszard, A (2007). Tannin: the new natural antioxidants. Eur. J. Lipid Sci. Technol. 109:549551.

Salawu, SO; Akindahunsi, AA; Comuzzo, P (2006). Chemical composition and in vitro Antioxidant activities of some Nigerian vegetables. J. Pharm. Toxicol. 1:429-437.

Satish, KT; Baskar, SS; Rajasekaren, PS; Manikandan, V (2008). Optimization of flavonoids extraction from the leaves of Tabernaemontana Heyneana Wall. Using L16 orthodesign. Nat. Sci., 6(3): 10-21.

Udodeme, HO; Omeke, CP; Nwafor, FI; Ezugwu, CO (2019). Antioxidant and Hepatoprotective properties from the Extract and Fractions of Annona senegalensis Pers (Annonaceae) stem bark grown in Nigeria. Eur. J. Med. Plants. 28(4): $1-13$. 